\title{
O RAZVOJU FIZIČNE GEOGRAFIJE V SLOVENIJI IN NJENIH SODOBNIH IZZIVIH
}

\author{
Ivan Gams \\ Akad. prof. dr., zaslužni profesor Univerze v Ljubljani v pokoju, \\ Ulica Pohorskega bataljona 185, 1000 Ljubljana, Slovenija.
}

\begin{abstract}
Izvleček
Članek prikazuje dosedanji razvoj fizične geografije v Sloveniji kot dela kompleksne geografske vede, katere vrh so regionalnogeografske monografije Slovenije. Avtor vidi izziv za bodoči razvoj fizične geografije v Sloveniji v konkurenci več, močnejših in bolje opremljenih inštitutov s podobnimi delovnimi področji. Edino kvantitativno vrednotenje izbranih pokrajinskih pojavov lahko po avtorjevih izkušnjah ohrani geografiji že standardno in še vedno edino preostalo vlogo v domoznanskih prostorskih znanostih. Kljub večjemu zanimanju javnosti za družbeno geografijo pa zagotavlja tudi fizični geografiji pomembno vlogo 2-3-krat povečan vpis slušateljev geografije na v zadnjih letih še razširjeno mrežo visokošolskih ustanov.
\end{abstract}

Ključne besede: geografija, fizična geografija, regionalna geografija, zgodovina geografije, Slovenija.

\section{ON THE DEVELOPMENT OF PHYSICAL GEOGRAPHY IN SLOVENIA AND ITS PRESENT CHALLENGES}

\begin{abstract}
The paper presents the development of physical geography in Slovenia as part of the complex geographical science, the topmost result of which have been the regional-geographical monographs on Slovenia. The author sees a challenge for the future development of physical geography in Slovenia in the competition of several, stronger and better equipped institutes with similar fields of work. According to the author's experience, only quantitative evaluation of the selected landscape phenomena can ensure the standard role, that is the only remaining role, of geography in local spatial sciences. Although public interest gives priority to human geography, physical geography, too, is granted an important role in view of the fact that the number of enrolled students of geography has been 2-3 times greater in the past few years in the extended network of high-school institutions.
\end{abstract}

Key words: geography, physical geography, regional geography, history of geography, Slovenia. 